\title{
The Use of Macroelements from Municipal Sewage Sludge by the Multiflora Rose and the Virginia fanpetals
}

\author{
Jacek Antonkiewicz ${ }^{*}$, Barbara Kołodziej², Elżbieta Jolanta Bielińska³, \\ Katarzyna Gleń-Karolczyk ${ }^{4}$ \\ 1 Department of Agricultural and Environmental Chemistry, University of Agriculture in Krakow, Poland \\ 2 Department of Industrial and Medicinal Plants, University of Life Sciences in Lublin, Poland \\ ${ }^{3}$ Institute of Soil Science, Environment Engineering and Management, University of Life Sciences in Lublin, \\ Lublin, Poland \\ ${ }^{4}$ Department of Agricultural Environment Protection, University of Agriculture in Krakow, Poland \\ * Corresponding author's e-mail: rrantonk@cyf-kr.edu.pl
}

\begin{abstract}
Municipal sewage sludge contains many valuable nutrients which can be used in the cultivation of energy crops. Application of large doses of sewage sludge can be a cause of environmental pollution, especially with nutrients. The multiflora rose and the Virginia fanpetals are plants with high nutritional requirements. The use of municipal sewage sludge in the cultivation of energy crops will allow recycling the nutrients from this organic waste. The aim of the study was to evaluate the use of macroelements from municipal sewage sludge by the multiflora rose var. "Jatar" (Rosa multiflora Thunb. ex Murray) and the Virginia fanpetals (Sida hermaphrodita Rusby). Four levels of sewage sludge fertilization were applied in the 6-year field experiment: 0, 10, 20, 40,60 Mg DM sludge $\cdot$ ha $^{-1}$. Sewage sludge was applied once before planting energy crops. Due to the low potassium content in sewage sludge, a single supplementary fertilization with $100 \mathrm{~kg} \mathrm{~K} \cdot \mathrm{ha}^{-1}$ in the form of $40 \%$ potassium salt $(\mathrm{KCl})$ was applied on each plot. The study involved the evaluation of the yield, uptake and use by energy plants of $\mathrm{N}, \mathrm{P}, \mathrm{K}, \mathrm{Ca}, \mathrm{Mg}$, and $\mathrm{Na}$ from sewage sludge. It was found that the increasing doses of sewage sludge significantly raised the multiflora rose and the Virginia fanpetals biomass yields. The yield of the Virginia fanpetals was one and a half times higher than that of the multiflora rose. The increasing doses of sewage sludge significantly raised the contents and uptake of $\mathrm{N}, \mathrm{P}, \mathrm{K}, \mathrm{Ca}, \mathrm{Mg}$, and $\mathrm{Na}$ by these plants. The highest uptake of macronutrients by the multiflora rose and the Virginia fanpetals crops was determined for $60 \mathrm{Mg} \mathrm{DM} \cdot \mathrm{ha}^{-1}$ fertilization dose. The results show that the Virginia fanpetals used $\mathrm{N}, \mathrm{P}, \mathrm{K}, \mathrm{Ca}, \mathrm{Mg}$, and $\mathrm{Na}$ from the sewage sludge to a greater extent than the multiflora rose. The analyses indicate that due to the greater yields, bioaccumulation and uptake of macronutrients, Virginia fanpetals is more effective in the 'purification' of the substrate from excess nutrients that may pose a threat to the environment.
\end{abstract}

Keywords: multiflora rose, Virginia fanpetals, macroelements, phytoremediation, municipal sewage sludge

\section{INTRODUCTION}

The application of municipal sewage sludge in the cultivation of energy crops is one of the alternative methods of its disposal [Nahm, Morhart 2018; Kołodziej et al. 2015]. The high content of organic matter (more than $50 \%$ on average) is the property of sewage sludge that favors its natural management [Helios et al. 2014]. What is more, municipal sewage sludge contains almost all nutrients necessary for plants. Cultivation of energy crops usually requires high contents of ni- trogen and phosphorus, which can be greater than in natural fertilizers [Zapałowska et al. 2017]. In turn, the amount of potassium in sewage sludge is lower than in organic fertilizers, composts, and natural fertilizer [Awasthi et al. 2017]. Additionally, after its application to the soil, municipal sewage sludge improves its physical, chemical and biological properties [Abdul Khaliq et al. 2017]. Unfortunately, sewage sludge may also contain significant amounts of heavy metals that can make it inadequate for natural management [Regulation 2015]. The excessive application of 
sewage sludge may result in soil contamination with nutrients that may contribute to water eutrophication [Lee et al. 2018]. Previous studies show that the management of municipal sewage sludge in the cultivation of energy and industrial plants may be an alternative method of nutrient recycling from this waste [Antonkiewicz 2010; Nahm, Morhart 2018].

With appropriate fertilization, energy crops are characterized by high yields and effectiveness in using nutrients [Kołodziej et al. 2016]. Previous studies showed that plants such as the Virginia fanpetals and the multiflora rose are very effective in the extraction of heavy metals from sewage sludge [Antonkiewicz et al. 2017; Korzeniowska, Stanisławska-Glubiak 2015]. Therefore, studies were carried out in order to determine the suitability of these species for phytoextraction of nutrients from municipal sewage sludge.

The aim of the study was to evaluate, under field conditions, which species are most effective in the use (phytoextraction) of $\mathrm{N}, \mathrm{P}, \mathrm{K}, \mathrm{Ca}, \mathrm{Mg}$, and $\mathrm{Na}$ from municipal sewage sludge. The phytoextraction potential of the tested energy crops was assessed taking into account the yield, content, uptake, and balance of macroelements, stating the increase, decrease and use of these components.

The selection of the energy plant species with the best efficiency and suitability for biomass production for energy purposes and with high phytoextraction capabilities was important for the implementation of the above-mentioned study objective [Antonkiewicz et al. 2017; Korzeniowska, Stanisławska-Glubiak 2015]. This constitute a proposal of a solution for the development of wastelands, marginal soils, and post-industrial areas, where there is usually no agricultural production or cultivation of consumer crops, and such development can bring a positive ecological and economic effect [Nahm, Morhart 2018; Schröder et al. 2018].

\section{MATERIAL AND METHODS}

The studies on the effect of increasing doses of municipal sewage sludge on the use of macroelements by the multiflora rose and the Virginia fanpetals were carried out in 2008-2013 in a municipal wastewater treatment plant in Janów Lubelski [50 $43^{\prime} 17.7^{\prime} \mathrm{N} 22^{\circ} 22^{\prime} 08,0^{\prime \prime E}$ ] located in southeastern Poland. This study is a continuation of the research on the extraction of heavy metals from municipal sewage sludge by the afore-mentioned plant species [Antonkiewicz et al. 2017].

\section{Soil and municipal sewage sludge}

The soil on which the experiment was set up is classified as clay loam (CL) (Table 1) [Polish Soil Classification 2011; Soil Survey Staff 2014]. The soil had slightly acidic pH, low available phosphorus and potassium contents, and very low magnesium content. The content of $\mathrm{Cr}, \mathrm{Ni}, \mathrm{Cu}$, $\mathrm{Zn}, \mathrm{Cd}$, and $\mathrm{Pb}$ in the soil did not exceed the limit values for the reclamation of municipal sewage sludge [Regulation 2016].

The municipal sewage sludge came from the municipal wastewater treatment plant in Janów Lubelski and this organic waste, catalog number 190805 [Waste Catalogue 2014], was stabilized and sanitized before use. The municipal sewage sludge was applied once in late autumn 2007 - it was mixed with a $20 \mathrm{~cm}$ surface layer of soil. Due to the low potassium content in sewage sludge, a single supplementary fertilization with $100 \mathrm{~kg} \mathrm{~K} \cdot \mathrm{ha}^{-1}$ in the form of $40 \%$ potassium salt $(\mathrm{KCl})$ was applied on each plot. No phosphorus fertilization was used in the field experiment, because the element content in the municipal sewage sludge satisfied the energy plants' demand for this component. The determined contents of $\mathrm{Cr}$, $\mathrm{Ni}, \mathrm{Cu}, \mathrm{Zn}, \mathrm{Cd}, \mathrm{Pb}$, and $\mathrm{Hg}$ in the municipal sewage sludge did not exceed the limit values for the reclamation of this waste [Regulation 2015]. No microbiological contamination was discovered in the sewage sludge used in the experiment.

\section{Design and conditions of the experiment}

The two-factor field experiment was set up using the randomized block method on $14.4 \mathrm{~m}^{2}$ plots, in three replicates. The first experimental factor was the dose of municipal sewage sludge. The experimental design consisted of 5 treatments: 1) control; 2) $10 \mathrm{Mg} \mathrm{DM}$; 3$) 20 \mathrm{Mg} \mathrm{DM}$; 4) $40 \mathrm{Mg} \mathrm{DM}$; and 5) $60 \mathrm{Mg}$ DM of municipal sewage sludge/ 1 ha. The second experimental factor comprised two species of energy plants: the multiflora rose var. "Jatar" (Rosa multiflora Thunb. ex Murr.) and the Virginia fanpetals (Sida hermaphrodita Rusby).

Woody cuttings ( $25 \mathrm{~cm}$ long) of the multiflora rose and roots sections $(8-12 \mathrm{~cm}$ long with several buds) of Virginia fanpetals were planted on April 22, 2008 at a spacing of $0.75 \times 0.8 \mathrm{~m}$ and $0.75 \times 0.4 \mathrm{~m}$, respectively. 
The determination of dry matter yield, macroelements content and soil enzymatic activity

Each year (2008-2013), the tested crops were harvested in autumn, at the turn of October and November. After the annual harvest, the plant material from each plot was dried at $70^{\circ} \mathrm{C}$ in a forced air circulation dryer, and, subsequently, the air-dry mass was determined. The samples of the analyzed plants were subjected to dry mineralization in a muffle furnace at $450^{\circ} \mathrm{C}$ [Ostrowska et al. 1991].

After microwave digestion in a mixture of concentrated $\mathrm{HCl}$ and $\mathrm{HNO}_{3}(3: 1, \mathrm{v} / \mathrm{v})$, the contents of elements ( $\mathrm{P}, \mathrm{K}, \mathrm{Na}, \mathrm{Mg}$, and $\mathrm{Ca}$ ) determined in the air-dried samples of soil and municipal sewage sludge were similar to the total contents [Ostrowska et al. 1991]. After mineralization of plant and soil material, the contents of these elements were determined using an ICPOES (Inductively Coupled Plasma - Optical Emission Spectroscopy) emission spectrometer [Jones and Case 1990]. Total nitrogen content in the tested plants (plant material) and municipal sewage sludge was determined by the Kjeldahl distillation method [Ostrowska et al. 1991].

The soil $\mathrm{pH}$ in $1 \mathrm{~mol} \cdot \mathrm{dm}^{-3} \mathrm{KCl}$ was determined with potentiometric method, the available $\mathrm{P}$ and $\mathrm{K}$ content was determined using the Egner-Riehm method, while the available $\mathrm{Mg}$ content was determined according to the Schachtschabel method (Ostrowska et al. 1991). Each year, during the vegetation season, in May, soil samples were collected from each plot (each repetition) from 0.20 $\mathrm{cm}$ depth, using the Egner's soil probe sampler, in order to assess the enzymatic activity of the soil. The analyses of the soil also involved determinations pertaining to the activities of enzymes which play a key role in the stable mineralization of organic matter and in supplying nutrients to the roots of energy crops. The activity of the studied enzymes was determined using the following methods: the activity of dehydrogenases with a TTC (triphenyl tetrazolium chloride) substrate using the Thalmann method (Thalmann 1968); the activity of acid phosphatase and alkaline phosphatase using the Tabatabai and Bremner method (Tabatabai and Bremner 1969); the activity of urease using the Zantua and Bremner method (Zantua and Bremner 1975); the activity of protease using the Ladd and Butler method (Ladd and Butler 1972). The activity of dehydrogenases was given in $\mathrm{cm}^{3} \mathrm{H}_{2}$, necessary for reducing TTC to TFP (triphenyl phormo- san); of phosphatases - in mmols of p-nitrophenol (PNP) produced from sodium 4-nitrophenylphosphate; urease - in $\mathrm{mg} \mathrm{N}^{-\mathrm{NH}_{4}+}$ generated from hydrolyzed urea; protease - in $\mathrm{mg}$ tyrosine developed from sodium caseinate. The results of the analyses pertaining to the enzymatic activity of the soil were presented in the paper as means for the six years of studies, i.e. for the 2008-2013 period.

\section{Analytical quality control}

The ICP-OES Optima 7300 DV, atomic emission spectrometer from Perkin Elmer Company was used for the determination of macroelements in plant and soil materials. Determinations in each of the analyzed samples were carried out in three replications. The quantitative analysis mode was used for the data acquisition of the samples. The scanning of each single sample was repeated three times to gather reasonably good results. During measurements, care was taken to avoid the memory effect and therefore a wash-out time of $0.5 \mathrm{~min}$ was used. The accuracy of the analytical methods was verified based on certified reference materials: CRM IAEA/V - 10 Hay (International Atomic Energy Agency), CRM - CD281 - Rey Grass (Institute for Reference Materials and Measurements), CRM023-050 - Trace Metals - Sandy Loam 7 (RT Corporation).

\section{Computations and statistical analysis}

Due to the cultivation of various plant species and the variability of conditions in individual years, the contents of $\mathrm{N}, \mathrm{P}, \mathrm{K}, \mathrm{Na}, \mathrm{Mg}$, and $\mathrm{Ca}$ in the total plant yield is presented as the weighted average from 2008-2013. The macroelement uptake (U) was computed by multiplying the dry matter yield $(\mathrm{Y})$ and macroelement content $(\mathrm{C})$ according to the formula: $U=Y \cdot C$. The macroelement balance (B) was computed as a difference between the amount of elements introduced (I) with the sewage sludge dose and the amount of macronutrients uptaken $(\mathrm{U})$ with the plant yield, according to the formula: $\mathrm{B}=\mathrm{I}-\mathrm{U}$. The simplified balance did not include the supply of macroelements from atmospheric precipitation, mineralization of organic matter, and leaching of macroelements into the soil profile. The phytoremediation of macroelements presented in the balance constitutes the percentage of macronutrient uptake by plants in relation to the amounts introduced into the soil with municipal sewage sludge. 
The statistical analysis of the results was carried out using the Microsoft Office Excel 2003 spreadsheet and the Statistica v. 10 PL package. The statistical evaluation of the variability of the results was carried out using the two-way analysis of variance. The significance of differences between mean values was verified based on the Tukey's t-test at the significance level of $\alpha \leq$ 0.05 . The value of Pearson's linear correlation coefficient ( $\mathrm{r}$ ) was calculated for some relations (parameters) at $\mathrm{p} \leq 0.05$. A maximum $5 \%$ dispersion of measurements in a chemical analysis was assumed in the study.

\section{RESULTS}

\section{Plant yield}

The dry mass yields of the multiflora rose and the Virginia fanpetals obtained in individual years of investigations were presented in an earlier publication [Antonkiewicz et al. 2017].

Plant yielding was an important indicator of the plant's response to the sewage sludge applied. The average yield of energy crops obtained from several years (2008-2013) ranged from 3.42 to 14.78 Mg DM $\cdot \mathrm{ha}^{-1}$ and depended on the sewage sludge dose and plant species (Figure 1). Close correlations between the dose of sewage sludge and the average yield of energy crops $(r=0.771375)$ were demonstrated in the field experiment.

During the multi-year research cycle, it was shown that a single application of $10-60 \mathrm{Mg}$
DM $\cdot \mathrm{ha}^{-1}$ of sewage sludge significantly increased plant yields compared to the control. The application of the largest dose of sewage sludge $\left(60 \mathrm{Mg} \mathrm{DM} \cdot \mathrm{ha}^{-1}\right)$ resulted in an increase in the average yield of the multiflora rose and Virginia fanpetals by over $264 \%$ and $90 \%$, respectively, in relation to the control (Figure 1). The study showed that the multiflora rose responded to the application of sewage sludge with a higher yield increase compared to the Virginia fanpetals.

On the other hand, when comparing the yield of energy crops, one could notice that the yield potential of the Virginia fanpetals was greater than that of the multiflora rose. The greatest difference in plant yielding was noted in the control treatment where neither mineral nor organic fertilizations were applied. The difference between the species in the control treatment was over $128 \%$. Subsequent doses of sewage sludge decreased the differences in yields between the tested species (for the highest dose of sewage sludge, the difference between these species was over $18 \%$ ). The study showed that the largest yield-forming effect for the multiflora rose and the Virginia fanpetals was achieved in the treatment where sewage sludge at a dose of 60 $\mathrm{Mg} \cdot \mathrm{ha}^{-1} \mathrm{DM}$ was applied (Figure 1).

\section{Macroelement content in plants}

The chemical analysis showed that the content of $\mathrm{N}, \mathrm{P}$, and $\mathrm{Na}$ in the municipal sewage sludge was over $72.7 ; 34.7$; and 8.3 -fold higher, respectively, compared to the topsoil (Table 1). In

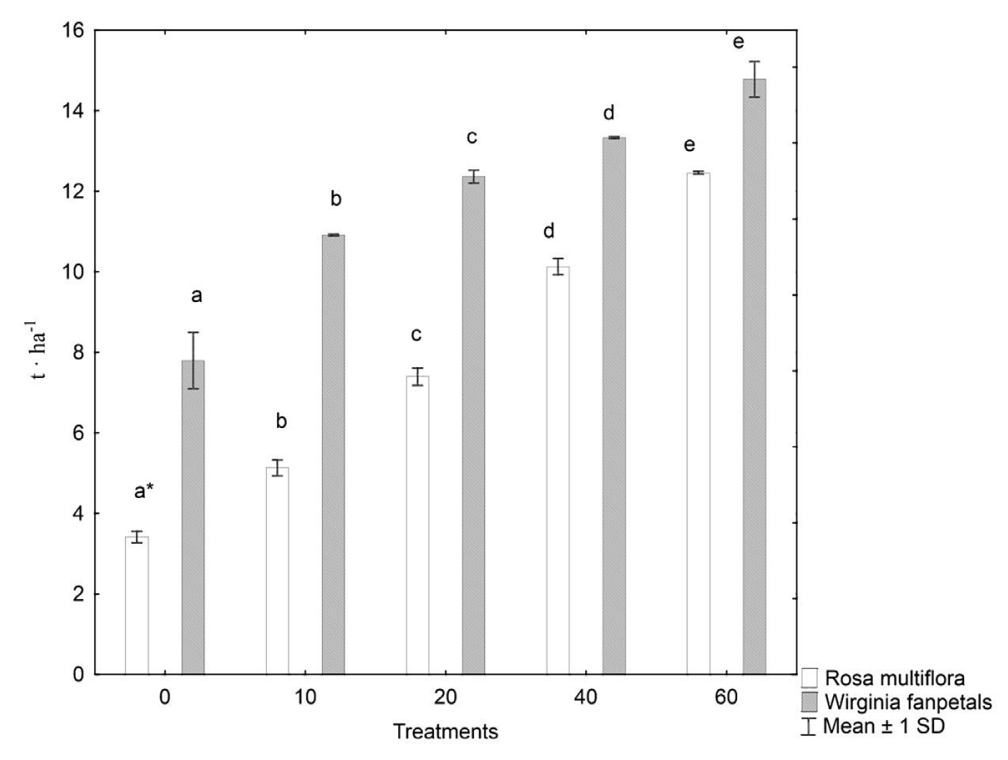

Figure 1. The average yield of the energy crops 
contrast, the total contents of $\mathrm{K}, \mathrm{Mg}$, and $\mathrm{Ca}$ in soil were over $1.0 ; 0.3 ; 2.1$-fold higher that these contents determined in sewage sludge. The investigations revealed that the applied municipal sewage sludge was a potential source of N, P, and $\mathrm{Na}$ for energy crops. The total contents of $\mathrm{K}, \mathrm{Mg}$, and $\mathrm{Ca}$ determined in the soil can be taken into account for the assessment of their bioavailability for plants, due to their presence in hardly accessible forms (e.g. soil minerals).

The macroelement content in the energy plants obtained in the control treatment was the lowest compared to the treatments with sewage sludge applied (Table 2). The use of increasing doses of sewage sludge $\left(10-60 \mathrm{Mg} \mathrm{DM} \cdot \mathrm{ha}^{-1}\right)$ significantly raised the content of macroelements in energy plants.

The largest increases in the content of macroelements in energy crops were recorded after the use of sewage sludge at a dose of $60 \mathrm{Mg} \mathrm{DM} \cdot \mathrm{ha}^{-1}$. In the case of the multiflora rose, the increase in macroelement content was: $74 \%$ for N, $95 \%$ for $\mathrm{P}, 58 \%$ for $\mathrm{K}, 37 \%$ for $\mathrm{Na}, 33 \%$ for $\mathrm{Mg}$ and $\mathrm{Ca}$, respectively, relative to the control. For the Virginia fanpetals biomass, the highest increase in macronutrients was: $82 \%$ for $\mathrm{N}, 81 \%$ for $\mathrm{P}, 49 \%$ for $\mathrm{K}, 40 \%$ for $\mathrm{Na}, 77 \%$ for $\mathrm{Mg}$, and $53 \%$ for $\mathrm{Ca}$, respectively, relative to the control. The investigations showed that regardless of the plant species, the application of the highest dose of sewage sludge resulted in the increase in the contents of the tested elements: the $\mathrm{P}$ and $\mathrm{N}$ content was raised the most, then $\mathrm{Mg}$ and $\mathrm{K}$, and the lowest content increase was recorded for $\mathrm{Ca}$ and $\mathrm{Na}$.

At the highest dose of sewage sludge, the Virginia fanpetals accumulated more $\mathrm{N}, \mathrm{Mg}, \mathrm{Ca}$, and $\mathrm{Na}$ than the multiflora rose. The multiflora rose exhibited higher contents of $\mathrm{P}$ and $\mathrm{K}$ than the Virginia fanpetals. The research proved that increasing doses of sewage sludge differentiated the content of macroelements in the tested energy plant species.

The analysis of the Pearson's linear correlation coefficient $(r)$ revealed close relationships between the sewage sludge dose and the content of $\mathrm{N}, \mathrm{P}, \mathrm{K}, \mathrm{Na}, \mathrm{Mg}, \mathrm{Ca}$ in energy plants $(\mathrm{r}=0.859526-0.966288)$. Additionally, a strong link between the amount of plant biomass and the content of the macroelements was discovered in these plants $(r=0.761727-0.954657)$. The correlations mentioned above indicate a significant effect of sewage sludge on the quality of biomass, evaluated in terms of energy as well as phytoremediation.

Table 1 Selected physical and chemical properties of the soil before experiment establishment and chemical composition of municipal sewage sludge used

\begin{tabular}{|c|c|c|c|c|}
\hline \multirow{2}{*}{ Parameter } & \multirow{2}{*}{ Unit } & \multicolumn{2}{|c|}{ Content in the soil layer } & \multirow{2}{*}{$\begin{array}{c}\text { Content in } \\
\text { sewage sludge }\end{array}$} \\
\hline & & $0-20 \mathrm{~cm}$ & $20-40 \mathrm{~cm}$ & \\
\hline Fraction $2-0.05 \mathrm{~mm}$ & \multirow{3}{*}{$\%$} & 32 & 23 & - \\
\hline Fraction $0.05-0.002 \mathrm{~mm}$ & & 39 & 45 & - \\
\hline Fraction $<0.002 \mathrm{~mm}$ & & 29 & 32 & - \\
\hline $\mathrm{pH}_{\mathrm{KCl}}$ & & 6.29 & 6.44 & 6.04 \\
\hline Organic matter & $\mathrm{g} \cdot \mathrm{kg}^{-1} \mathrm{DM}$ & 14.5 & 14.1 & 594.0 \\
\hline Available phosphorus $(\mathrm{P})$ & \multirow{3}{*}{$\mathrm{mg} \cdot \mathrm{kg}^{-1} \mathrm{DM}$} & 30.9 & 29.6 & 2.25 \\
\hline Available potassium (K) & & 91.3 & 60.6 & $\mathrm{Bdl}^{*}$ \\
\hline Available magnesium (Mg) & & 27.6 & 24.6 & 0.28 \\
\hline Total nitrogen $(\mathrm{N})$ & & 1.01 & - & 74.5 \\
\hline Total phosphorus (P) & & 0.35 & - & 12.5 \\
\hline Total potassium $(\mathrm{K})$ & $\mathrm{g} \cdot \mathrm{kg}^{-1} \mathrm{DM}$ & 3.83 & - & 1.90 \\
\hline Total sodium $(\mathrm{Na})$ & & 0.16 & - & 1.50 \\
\hline Total magnesium (Mg) & & 3.71 & - & 2.80 \\
\hline Total calcium (Ca) & & 8.95 & - & 2.90 \\
\hline Total chromium $(\mathrm{Cr})$ & \multirow{6}{*}{$\mathrm{mg} \cdot \mathrm{kg}^{-1} \mathrm{DM}$} & 9.66 & 9.89 & 25.4 \\
\hline Total nickel (Ni) & & 6.39 & 6.31 & 14.8 \\
\hline Total copper $(\mathrm{Cu})$ & & 3.20 & 3.60 & 111 \\
\hline Total zinc (Zn) & & 31.97 & 31.00 & 1005 \\
\hline Total cadmium $(\mathrm{Cd})$ & & $<0.27$ & $<0.27$ & 2.35 \\
\hline Total lead $(\mathrm{Pb})$ & & 13.67 & 13.63 & 42.9 \\
\hline
\end{tabular}

${ }^{*} \mathrm{Bdl}$ - Below detection level 
Table 2 Weighted average of macroelement content in energy plants $\left(\mathrm{g} \cdot \mathrm{kg}^{-1} \mathrm{DM}\right)$

\begin{tabular}{|c|c|c|c|c|c|c|}
\hline Treatments & $N$ & $P$ & K & $\mathrm{Na}$ & $\mathrm{Mg}$ & $\mathrm{Ca}$ \\
\hline $\begin{array}{l}\text { Sludge dose } \\
\left(\mathrm{Mg} \mathrm{DM} \cdot \mathrm{ha}^{-1}\right)\end{array}$ & \multicolumn{6}{|c|}{ Rosa multiflora } \\
\hline 0 & 9.4 & 0.6 & 3.0 & 0.2 & 0.7 & 7.4 \\
\hline 10 & 12.6 & 0.6 & 3.2 & 0.2 & 0.8 & 7.9 \\
\hline 20 & 14.4 & 0.7 & 3.7 & 0.2 & 0.8 & 8.5 \\
\hline 40 & 15.8 & 0.7 & 4.1 & 0.3 & 0.9 & 9.4 \\
\hline 60 & 16.3 & 1.1 & 4.8 & 0.3 & 1.0 & 9.8 \\
\hline Mean & 13.7 & 0.7 & 3.7 & 0.2 & 0.8 & 8.6 \\
\hline CV $(\%)^{*}$ & 19.4 & 28.9 & 18.9 & 12.8 & 11.9 & 12.5 \\
\hline $\begin{array}{l}\text { Sludge dose } \\
\left(\mathrm{Mg} \mathrm{DM} \cdot \mathrm{ha}^{-1}\right)\end{array}$ & \multicolumn{6}{|c|}{ Sida hermaphrodita } \\
\hline 0 & 8.8 & 0.4 & 2.5 & 0.2 & 0.4 & 3.4 \\
\hline 10 & 10.5 & 0.5 & 2.7 & 0.2 & 0.4 & 3.8 \\
\hline 20 & 13.7 & 0.5 & 2.9 & 0.3 & 0.6 & 4.2 \\
\hline 40 & 14.4 & 0.6 & 3.2 & 0.3 & 0.7 & 4.7 \\
\hline 60 & 16.1 & 0.7 & 3.7 & 0.3 & 0.8 & 5.2 \\
\hline Mean & 12.7 & 0.6 & 3.0 & 0.3 & 0.6 & 4.3 \\
\hline CV $(\%)^{*}$ & 21.8 & 21.4 & 14.5 & 17.4 & 26.2 & 16.1 \\
\hline $\begin{array}{c}\text { Sludge dose } \\
\left(\mathrm{Mg} \mathrm{DM} \cdot \mathrm{ha}^{-1}\right)\end{array}$ & \multicolumn{6}{|c|}{ Mean for dose of the sewage sludge } \\
\hline 0 & 9.1 & 0.5 & 2.7 & 0.2 & 0.6 & 5.4 \\
\hline 10 & 11.5 & 0.6 & 3.0 & 0.2 & 0.6 & 5.8 \\
\hline 20 & 14.0 & 0.6 & 3.3 & 0.3 & 0.7 & 6.4 \\
\hline 40 & 15.1 & 0.6 & 3.6 & 0.3 & 0.8 & 7.0 \\
\hline 60 & 16.2 & 0.9 & 4.2 & 0.3 & 0.9 & 7.5 \\
\hline LSD for dose** & 0.40 & 0.05 & 0.18 & 0.01 & 0.03 & 0.34 \\
\hline LSD for species & 0.63 & 0.08 & 0.28 & 0.01 & 0.05 & 0.54 \\
\hline LSD for interaction & 0.89 & 0.11 & 0.40 & 0.02 & 0.07 & 0.77 \\
\hline
\end{tabular}

${ }^{*} \mathrm{CV}$ - Variability Coefficient

${ }^{* *}$ LSD - Least Significant Differences

\section{Macroelement uptake by plants}

Table 3 shows the macroelement uptake by energy plants as the sum of data from the entire experiment period, i.e. 2008-2013.

The amount of macroelements taken up by the tested species depended on the yield and the content of elements in individual species (Figure 1, Table 2). Increasing doses of municipal sewage sludge significantly raised the uptake of $\mathrm{N}, \mathrm{P}, \mathrm{K}$, $\mathrm{Na}, \mathrm{Mg}$, and $\mathrm{Ca}$ with the yield of energy crops (Table 3). The lowest macroelement uptake with the yield of multiflora rose and Virginia fanpetals was determined in the control treatment where no sewage sludge was applied. On the other hand, the largest macroelement uptake with the yield of the tested species was found in the treatment with the maximum dose of sewage sludge. The increase in the $\mathrm{N}, \mathrm{P}, \mathrm{K}, \mathrm{Na}, \mathrm{Mg}$, and $\mathrm{Ca}$ uptake by the multiflora rose, after the application of $60 \mathrm{Mg} \mathrm{DM} \cdot \mathrm{ha}^{-1}$ of sewage sludge was over
$534 \%$; $611 \%$; 477\%; 401\%; 394\%, and $387 \%$, respectively, higher than for the control treatment. In the case of Virginia fanpetals, the increase in the $\mathrm{N}, \mathrm{P}, \mathrm{K}, \mathrm{Na}, \mathrm{Mg}$, and $\mathrm{Ca}$ uptake at the highest dose of sewage sludge was over $245 \% ; 244 \%$; $183 \% ; 166 \% ; 235 \%$, and $190 \%$, respectively, compared to the control treatment. The investigations showed that the increasing doses of sewage sludge made the multiflora rose respond with more intensive macroelement uptake compared to the Virginia fanpetals (Table 3).

A comparison of the macroelement uptake at the highest dose of sewage sludge revealed a greater uptake of $\mathrm{N}$ and $\mathrm{Na}$ with the biomass yield by the Virginia fanpetals than by the multiflora rose. On the other hand, the multiflora rose took up more $\mathrm{P}, \mathrm{K}, \mathrm{Mg}$, and $\mathrm{Ca}$ than the Virginia fanpetals. The study showed that the greatest difference in the amount of macroelements taken up by the tested plant species was recorded in the control treatment where no sewage sludge was applied. 
Table 3. Total macroelement uptake by energy plants $\left(\mathrm{kg} \cdot \mathrm{ha}^{-1}\right)$

\begin{tabular}{|c|c|c|c|c|c|c|}
\hline Treatments & $\mathrm{N}$ & $P$ & K & $\mathrm{Na}$ & $\mathrm{Mg}$ & $\mathrm{Ca}$ \\
\hline $\begin{array}{l}\text { Sludge dose } \\
\left(\mathrm{Mg} \mathrm{DM} \cdot \mathrm{ha}^{-1}\right)\end{array}$ & \multicolumn{6}{|c|}{ Rosa multiflora } \\
\hline 0 & 192.0 & 11.6 & 61.7 & 4.4 & 14.8 & 150.9 \\
\hline 10 & 388.3 & 18.9 & 98.9 & 6.8 & 24.1 & 244.5 \\
\hline 20 & 636.5 & 29.6 & 162.0 & 10.6 & 36.8 & 379.0 \\
\hline 40 & 959.2 & 43.6 & 247.6 & 15.9 & 55.9 & 569.4 \\
\hline 60 & 1218.4 & 82.5 & 356.2 & 22.1 & 73.1 & 735.5 \\
\hline Mean & 678.9 & 37.3 & 185.3 & 12.0 & 40.9 & 415.8 \\
\hline CV $(\%)^{*}$ & 57.0 & 70.8 & 60.1 & 55.4 & 54.0 & 53.5 \\
\hline $\begin{array}{c}\text { Sludge dose } \\
\left(\mathrm{Mg} \mathrm{DM} \cdot \mathrm{ha}^{-1}\right)\end{array}$ & \multicolumn{6}{|c|}{ Sida hermaphrodita } \\
\hline 0 & 412.9 & 19.3 & 115.8 & 11.4 & 20.3 & 159.9 \\
\hline 10 & 684.7 & 32.0 & 179.8 & 14.0 & 26.0 & 246.6 \\
\hline 20 & 1013.0 & 39.3 & 218.6 & 21.0 & 47.0 & 312.4 \\
\hline 40 & 1148.2 & 45.5 & 257.6 & 24.4 & 56.3 & 375.3 \\
\hline 60 & 1426.9 & 66.5 & 327.8 & 30.3 & 68.1 & 465.1 \\
\hline Mean & 937.2 & 40.5 & 219.9 & 20.2 & 43.5 & 311.8 \\
\hline $\mathrm{CV}(\%)^{*}$ & 39.3 & 40.3 & 33.8 & 35.5 & 43.1 & 35.0 \\
\hline $\begin{array}{l}\text { Sludge dose } \\
\left(\mathrm{Mg} \mathrm{DM} \cdot \mathrm{ha}^{-1}\right)\end{array}$ & \multicolumn{6}{|c|}{ Mean for dose of the sewage sludge } \\
\hline 0 & 302.4 & 15.5 & 88.7 & 7.9 & 17.5 & 155.4 \\
\hline 10 & 536.5 & 25.5 & 139.3 & 10.4 & 25.0 & 245.5 \\
\hline 20 & 824.8 & 34.5 & 190.3 & 15.8 & 41.9 & 345.7 \\
\hline 40 & 1053.7 & 44.6 & 252.6 & 20.1 & 56.1 & 472.3 \\
\hline 60 & 1322.6 & 74.5 & 342.0 & 26.2 & 70.6 & 600.3 \\
\hline LSD for dose** & 25.77 & 3.29 & 12.17 & 0.62 & 2.22 & 20.53 \\
\hline LSD for species & 40.75 & 5.20 & 19.25 & 0.98 & 3.51 & 32.45 \\
\hline LSD for interaction & 57.62 & 7.36 & 27.22 & 1.39 & 4.97 & 45.90 \\
\hline
\end{tabular}

* CV - Variability Coefficient

** LSD - Least Significant Differences

Significant correlations between the dose of sewage sludge and the macroelement uptake by the tested species was demonstrated $(\mathrm{r}=$ $0.836856-0.971657)$. The uptake of macroelements by plants was also strongly correlated with the mean yield of the tested species $(\mathrm{r}=$ $0.582655-0.963922)$. The study also showed significant relationships between the content of macroelements in plants and their uptake $(\mathrm{r}=$ $0.813716-0.90496)$.

\section{Simplified balance and macroelement phytoremediation}

The use of municipal sewage sludge in the postindustrial areas, poor in nutrients will increase the amount of macroelements available there.

Understanding the macroelement cycle in the soil-plant system will allow a better assessment of the use of these components from organic waste. Such an assessment can be made on the basis of a simplified balance of macroelements and phytoremediation.

The macroelement balance was determined by the introduction of components with sewage sludge and the total uptake of macroelements with the plant yield (Table 4). In control treatments where no sewage sludge was applied, the total balance of macroelements was always negative. The negative balance resulted from the simplified balance which did not include the supply of macroelements from external sources (amounts available in soil, mineralization of organic matter, atmospheric precipitation).

In the treatments fertilized with sewage sludge, a negative balance for $\mathrm{K}$ and $\mathrm{Ca}$ was also determined. This balance indicates that $\mathrm{K}$ and $\mathrm{Ca}$ were taken up by the tested species in larger amounts, compared to the amounts introduces with a sewage sludge dose. 
Table 4. Simplified balance of macroelements after six years of research

\begin{tabular}{|c|c|c|c|c|c|c|c|}
\hline \multirow{3}{*}{ Treatments } & Introduced & Uptake & Balance & \multirow{2}{*}{$\begin{array}{c}\text { Recovery } \\
\%\end{array}$} & Uptake & Balance & \multirow{2}{*}{$\begin{array}{c}\text { Recovery } \\
\%\end{array}$} \\
\hline & \multicolumn{3}{|c|}{$\mathrm{kg} \cdot \mathrm{ha}^{-1}$} & & \multicolumn{2}{|c|}{$\mathrm{kg} \cdot \mathrm{ha}^{-1}$} & \\
\hline & & \multicolumn{3}{|c|}{ Rosa multiflora } & \multicolumn{3}{|c|}{ Sida hermaphrodita } \\
\hline $\begin{array}{l}\text { Sludge dose } \\
\left(\mathrm{Mg} \mathrm{DM} \cdot \mathrm{ha}^{-1}\right)\end{array}$ & \multicolumn{7}{|c|}{$\mathrm{N}$} \\
\hline 0 & 0 & 192 & -192 & 0 & 413 & -413 & 0 \\
\hline 10 & 745 & 388 & 357 & 52 & 685 & 60 & 92 \\
\hline 20 & 1490 & 637 & 853 & 43 & 1013 & 477 & 68 \\
\hline 40 & 2980 & 959 & 2021 & 32 & 1148 & 1832 & 39 \\
\hline 60 & 4470 & 1218 & 3252 & 27 & 1427 & 3043 & 32 \\
\hline $\begin{array}{c}\text { Sludge dose } \\
\left(\mathrm{Mg} \mathrm{DM} \cdot \mathrm{ha}^{-1}\right)\end{array}$ & \multicolumn{7}{|c|}{$P$} \\
\hline 0 & 0 & 12 & -12 & 0 & 19 & -19 & 0 \\
\hline 10 & 125 & 19 & 106 & 15 & 32 & 93 & 26 \\
\hline 20 & 250 & 30 & 220 & 12 & 39 & 211 & 16 \\
\hline 40 & 500 & 44 & 456 & 9 & 45 & 455 & 9 \\
\hline 60 & 750 & 83 & 667 & 11 & 66 & 684 & 9 \\
\hline $\begin{array}{c}\text { Sludge dose } \\
\left(\mathrm{Mg} \mathrm{DM} \cdot \mathrm{ha}^{-1}\right)\end{array}$ & \multicolumn{7}{|c|}{ K } \\
\hline 0 & 0 & 62 & -62 & 0 & 116 & -116 & 0 \\
\hline 10 & 119 & 99 & 20 & 83 & 180 & -61 & 151 \\
\hline 20 & 138 & 162 & -24 & 117 & 219 & -81 & 158 \\
\hline 40 & 176 & 248 & -72 & 141 & 258 & -82 & 146 \\
\hline 60 & 214 & 356 & -142 & 166 & 328 & -114 & 153 \\
\hline $\begin{array}{c}\text { Sludge dose } \\
\left(\mathrm{Mg} \mathrm{DM} \cdot \mathrm{ha}^{-1}\right)\end{array}$ & \multicolumn{7}{|c|}{$\mathrm{Na}$} \\
\hline 0 & 0 & 4 & -4 & 0 & 11 & -11 & 0 \\
\hline 10 & 15 & 7 & 8 & 45 & 14 & 1 & 93 \\
\hline 20 & 30 & 11 & 19 & 35 & 21 & 9 & 70 \\
\hline 40 & 60 & 16 & 44 & 27 & 24 & 36 & 41 \\
\hline 60 & 90 & 22 & 68 & 25 & 30 & 60 & 34 \\
\hline $\begin{array}{l}\text { Sludge dose } \\
\left(\mathrm{Mg} \mathrm{DM} \cdot \mathrm{ha}^{-1}\right)\end{array}$ & \multicolumn{7}{|c|}{$\mathrm{Mg}$} \\
\hline 0 & 0 & 15 & -15 & 0 & 20 & -20 & 0 \\
\hline 10 & 28 & 24 & 4 & 86 & 26 & 2 & 93 \\
\hline 20 & 56 & 37 & 19 & 66 & 47 & 9 & 84 \\
\hline 40 & 112 & 56 & 56 & 50 & 56 & 56 & 50 \\
\hline 60 & 168 & 73 & 95 & 44 & 68 & 100 & 41 \\
\hline $\begin{array}{l}\text { Sludge dose } \\
\left(\mathrm{Mg} \mathrm{DM} \cdot \mathrm{ha}^{-1}\right)\end{array}$ & \multicolumn{7}{|c|}{$\mathrm{Ca}$} \\
\hline 0 & 0 & 151 & -151 & 0 & 160 & -160 & 0 \\
\hline 10 & 29 & 244 & -215 & 843 & 247 & -218 & 850 \\
\hline 20 & 58 & 379 & -321 & 653 & 312 & -254 & 539 \\
\hline 40 & 116 & 569 & -453 & 491 & 375 & -259 & 323 \\
\hline 60 & 174 & 735 & -561 & 423 & 465 & -291 & 267 \\
\hline
\end{tabular}

The increasing doses of sewage sludge caused the positive balance for $\mathrm{N}, \mathrm{P}, \mathrm{Na}$, and $\mathrm{Mg}$. This positive balance of the above-mentioned macroelements resulted from the greater supply of these components with sewage sludge compared to the amounts taken up by the tested plant species. The greatest balance difference for macroelements was determined in the treatments in which the highest dose of sewage sludge was applied. The balance difference resulted from the amount of macronutrients introduced into the soil.

The largest $\mathrm{N}, \mathrm{P}, \mathrm{Na}$, and $\mathrm{Mg}$ phytoremediation was recorded in treatments fertilized with the smallest doses of sewage sludge $\left(10 \mathrm{Mg} \mathrm{DM} \cdot \mathrm{ha}^{-1}\right)$. The increasing doses of sewage sludge systematically decreased phytoremediation in comparison 
with the lowest dose of sewage sludge. The lowest macroelement phytoremediation probably resulted from the size of the sewage sludge dose, yielding, and uptake of these components by the tested species.

Among the tested plant species, the Virginia fanpetals used $\mathrm{N}, \mathrm{P}, \mathrm{K}, \mathrm{Na}$, and $\mathrm{Mg}$ (phytoremediation) to a greater extent than the multiflora rose, which was related to the greater yielding and uptake of these elements. In the case of $\mathrm{Ca}$, greater phytoremediation of this element was determined for the multiflora rose than for the Virginia fanpetals.

It was found that among the evaluated macroelements, the percentage of $\mathrm{Ca}$ and $\mathrm{K}$ phytoremediation was the highest (more taken up than introduced). The second highest phytoremediation was exhibited by $\mathrm{Mg}, \mathrm{Na}$, and $\mathrm{N}$, and the last $\mathrm{P}$.

\section{Soil enzymatic activity}

The experiment also involved the examination of the soil enzymatic activity after applying the increasing doses of sewage sludge (Table 5). A significant effect of increasing the doses of sewage sludge on soil microorganisms and their enzymatic activity was revealed. The lowest enzymatic activity was determined in the control treatment.

In the case of the multiflora rose, at the highest sewage sludge dose $\left(60 \mathrm{Mg} \mathrm{DM} \cdot \mathrm{ha}^{-1}\right)$, we discovered an over 2.6, 2.0, 2.1, 2.0, 1.5-fold increase in the soil enzymatic activity for dehydrogenase, urease, protease, acid and alkaline phosphatases, respectively, compared to the control. In turn, for the Virginia fanpetals, the soil enzymatic activity increased over 2.9, 1.9, 2.1, 2.6, 2.4-fold, respectively, in comparison with the control treatment.

Table 5. Soil Enzymatic activity (average from 2008-2013)

\begin{tabular}{|c|c|c|c|c|c|}
\hline \multirow[t]{2}{*}{ Treatments } & $\begin{array}{c}\text { Dehydrogenases } \\
\text { activity }\end{array}$ & $\begin{array}{l}\text { Urease } \\
\text { activity }\end{array}$ & Protease activity & $\begin{array}{c}\text { Acid phosphatase } \\
\text { activity }\end{array}$ & $\begin{array}{c}\text { Alcaline } \\
\text { phosphatase } \\
\text { activity }\end{array}$ \\
\hline & $\left(\mathrm{cm}^{3} \mathrm{H}_{2} \cdot \mathrm{kg}^{-1} \cdot \mathrm{d}^{-1}\right)$ & $\begin{array}{c}\left(\mathrm{mg} \mathrm{N}-\mathrm{NH}_{4}^{+} \cdot\right. \\
\left.\mathrm{kg}^{-1} \cdot \mathrm{h}^{-1}\right)\end{array}$ & $\begin{array}{c}\text { (mg of tyrosine } \\
\mathrm{kg}^{-1} \cdot \mathrm{h}^{-1} \text { ) }\end{array}$ & $\begin{array}{c}\text { (mmol PNP } \\
\left.\mathrm{kg}^{-1} \cdot \mathrm{h}^{-1}\right)\end{array}$ & $\begin{array}{c}\text { (mmol PNP } \\
\left.\mathrm{kg}^{-1} \cdot \mathrm{h}^{-1}\right)\end{array}$ \\
\hline $\begin{array}{l}\text { Sludge dose } \\
\left(\mathrm{Mg} \mathrm{DM} \cdot \mathrm{ha}^{-1}\right)\end{array}$ & \multicolumn{5}{|c|}{ Rosa multiflora } \\
\hline 0 & 4.7 & 7.9 & 10.2 & 23.1 & 17.3 \\
\hline 10 & 4.8 & 9.7 & 10.8 & 24.2 & 17.6 \\
\hline 20 & 5.6 & 11.7 & 16.4 & 35.1 & 22.2 \\
\hline 40 & 8.4 & 16.7 & 24.4 & 72.2 & 51.7 \\
\hline 60 & 17.0 & 24.1 & 32.5 & 69.4 & 43.3 \\
\hline Mean & 8.1 & 14.0 & 18.9 & 44.8 & 30.4 \\
\hline $\mathrm{CV}(\%)^{*}$ & 59.8 & 43.4 & 47.1 & 50.1 & 49.3 \\
\hline $\begin{array}{l}\text { Sludge dose } \\
\left(\mathrm{Mg} \mathrm{DM} \cdot \mathrm{ha}^{-1}\right)\end{array}$ & \multicolumn{5}{|c|}{ Sida hermaphrodita } \\
\hline 0 & 4.3 & 7.5 & 10.5 & 26.3 & 18.1 \\
\hline 10 & 5.4 & 9.3 & 13.1 & 31.8 & 20.6 \\
\hline 20 & 7.6 & 12.1 & 17.5 & 43.4 & 28.4 \\
\hline 40 & 11.7 & 16.3 & 27.0 & 98.2 & 66.6 \\
\hline 60 & 16.9 & 22.2 & 32.6 & 95.7 & 63.0 \\
\hline Mean & 9.2 & 13.5 & 20.2 & 59.1 & 39.3 \\
\hline $\mathrm{CV}(\%)^{*}$ & 52.6 & 41.1 & 44.0 & 58.7 & 59.6 \\
\hline $\begin{array}{l}\text { Sludge dose } \\
\left(\mathrm{Mg} \mathrm{DM} \cdot \mathrm{ha}^{-1}\right)\end{array}$ & \multicolumn{5}{|c|}{ Mean for dose of the sewage sludge } \\
\hline 0 & 4.5 & 7.7 & 10.4 & 24.7 & 17.7 \\
\hline 10 & 5.1 & 9.5 & 12.0 & 28.0 & 19.1 \\
\hline 20 & 6.6 & 11.9 & 17.0 & 39.2 & 25.3 \\
\hline 40 & 10.0 & 16.5 & 25.7 & 85.2 & 59.1 \\
\hline 60 & 16.9 & 23.2 & 32.6 & 82.5 & 53.1 \\
\hline LSD for dose ${ }^{* *}$ & 0.52 & 0.80 & 1.40 & 7.74 & 5.64 \\
\hline LSD for species & 0.82 & 1.26 & 2.22 & 12.23 & 8.92 \\
\hline LSD for interaction & 1.16 & 1.79 & 3.14 & 17.30 & 12.62 \\
\hline
\end{tabular}

${ }^{*} \mathrm{CV}$ - Variability Coefficient

${ }^{* *}$ LSD - Least Significant Differences 
The investigations showed that regardless of the plant species, the application of the highest dose of sewage sludge resulted in the highest increase in the activity of dehydrogenase, and the lowest in the case of alkaline phosphatase. The field experiment revealed that the Virginia fanpetals stimulated greater activity of dehydrogenase, protease, as well as acid and alkaline phosphatases than the multiflora rose. On the other hand, the multiflora rose stimulated greater activity of urease than the Virginia fanpetals.

Large amounts of nutrients, organic colloids, and soil microorganisms were introduced with the municipal sewage sludge, which had a stimulating effect on the soil enzymes. This phenomenon was confirmed by significant correlations between the sewage sludge dose and soil enzymatic activity $(\mathrm{r}=0.816675-0.979479)$. The field experiment also showed a close link between the activity of soil enzymes and the yield of the tested plants $(r=0.721015-0.793485)$. The activity of soil enzymes was correlated with the content of macroelements in plants $(r=0.5497994-0.982658)$ as well. Significant relationships were also demonstrated between the activity of soil enzymes and the uptake of macroelements by the tested plant species $(r=0.626945-0.948615)$.

\section{DISCUSSION}

The use of the municipal sewage sludge in degraded, marginal, and post-industrial areas improves the physicochemical properties of these lands [Kicińska et al. 2018; Korzeniowska, Stanisławska-Glubiak2015]. Sewage sludge, apart from heavy metals, constitutes a potential source of macroelements which can be used in the cultivation of energy and industrial plants [Kołodziej et al. 2015; 2016; Zapałowska et al. 2017].

\section{Yield}

Our study proved that sewage sludge significantly increases yielding of the tested plants, which is confirmed by the earlier publications [Kołodziej et al. 2015; 2016]. The studies of Abdul Khaliq et al. [2017] and Helios et al. [2014] also confirm that the application of the municipal sewage sludge results in the energy plant yielding increase. Other studies showed that compared to other energy plants, the Virginia fanpetals had the highest biomass yields [Nahm, Morhart 2018]. The size of the Virginia fanpetals and multiflora rose biomass yields was comparable to the one obtained by the above-mentioned authors. According to Borkowska and Molas [2012, 2013], the Virginia fanpetals planted on sewage sludge has high yield potential.

\section{Macroelement content}

A significant increase in the macroelement content in the Virginia fanpetals and multiflora rose was found after the application of sewage sludge. According to Borkowska and Molas [2012, 2013] as well as Krzywy-Gawrońska [2012], the increase in the content of macroelements in energy plants is determined by the dose of sewage sludge and mineral fertilization, which was also confirmed by our study. Pogrzeba et al. [2018] indicated that mineral fertilization and the addition of microorganisms increased the macroelement content in the selected energy crops, which was confirmed by us. As stated by Wierzbowska et al. [2016] and Krzywy-Gawrońska [2012], increasing the doses of sewage sludge raised the contents of $\mathrm{N}, \mathrm{P}, \mathrm{K}, \mathrm{Na}, \mathrm{Ca}$, and $\mathrm{Mg}$ in the Virginia fanpetals, which confirms that this species is very effective in the use of macronutrients from these wastes. On the other hand, the study of Helios et al. [2014] reveled that sewage sludge used in the cultivation of prairie cordgrass (Spartina pectinata Link.) did not increase the macroelement content in this species. The lack of effect of sewage sludge on the increase of macronutrients in prairie cordgrass most probably resulted from a small dose of sewage sludge (1.4-4.2 Mg $\left.\mathrm{DM} \cdot \mathrm{ha}^{-1}\right)$ compared to the doses used in our study (10-60 Mg DM · ha-1), [Helios et al. 2014].

\section{Uptake}

Our study confirmed that the increasing doses of sewage sludge significantly raised the macroelement uptake by the tested plants compared to the control. Similar relationships were demonstrated by Wierzbowska et al. [2012], who proved that sewage sludge stimulates a greater uptake of macroelements by the Virginia fanpetals. The studies of Helios et al. [2014] confirmed that increasing doses of sewage sludge raises the macroelement uptake by the prairie cordgrass. Higher uptake of macroelements from sewage sludge by perennial and energy crops results, inter alia, from a long growing season (systematic uptake) and high yield potential [Korzeniowska, StanisławskaGlubiak 2015; Kocoń, Jurga 2017; Sienkiewicz 
et al. 2018]. According to Arduini et al. [2018], the converted sewage sludge (biosolid) affects the systematic uptake of macronutrients by crops. This author demonstrated that macronutrients derived from sewage sludge were taken up by plants in larger amounts than from mineral fertilizers. The greater uptake of macronutrients by plants results from the improvement of physicochemical properties of soil after the application of sewage sludge [Arduni et al. 2018; Schröder et al. 2018]. The analysis of world literature carried out by Nahm and Morhart [2018] indicated that the Virginia fanpetals is suitable for the effective uptake of nitrogen, and thus the removal of excess nutrients from the soil.

\section{Balance}

The presented balance shows that sewage sludge is a potential source of macroelements, especially N and P [Kacprzak et al. 2017; Zapałowska et al. 2018]. Sewage sludge can contain significant amounts of $\mathrm{Na}, \mathrm{Mg}$, and $\mathrm{Ca}-$ the elements originating from hygienisation and sewage treatment technology [Kacprzak et al. 2017]. The study showed that the balance of macroelements in treatments fertilized with sewage sludge was positive, which resulted from the amount of these components supplied with this waste. Other studies confirmed that sewage sludge used in large amounts affects the positive balance of these components in the soil [Wierzbowska et al. 2016]. A negative balance was determined for K. This is mainly due to the fact that sewage sludge was poor in this element, which is confirmed by other studies [Sienkiewicz et al. 2018; Tontti et al. 2017]. As indicated by Lee et al. [2018], sewage sludge constitutes a large source of macroelements that can be recovered for the environment. In general, sewage sludge can be used as an alternative source of macroelements to minimize the use of mineral fertilizers [Lee et al. 2018]. The high phytoremediation of macronutrients by the Virginia fanpetals was also recorded in the study of Wierzbowska [2016]. The effective use of nutrients from municipal sewage sludge is crucial for sustainable development and, at the same time, minimizes the effect of excessive nutrient applications on the environment [Sassenrath et al. 2013].

\section{Enzymatic activity}

Microorganisms support the use of soil macronutrients by plants [Pogrzeba et al. 2018]. Our ex- periment yielded high values of the activity of the tested enzymes, which confirms the effectiveness of the use of sewage sludge as an organic fertilizer in the cultivation of energy crops [Kołodziej et al. 2015; 2016; Wolna-Murawka et al. 2018]. The research carried out by Symanowicz et al. [2018] confirmed that mineral and organic fertilizations increase the soil enzymatic activity, and thus raise the macroelement uptake by plants.

In our study, the activity of soil enzymes increased significantly (progressively) along with the dose of sewage sludge, which was related to the amount of carbon substrates available for microorganisms and enzymes [Bielińska et al. 2015; Wolna-Murawka et al. 2018]. Our investigations and studies conducted by other authors confirmed that the Virginia fanpetals secretes root slime which stimulates the enzymatic activity of soil [Wielgosz 1999]. What is more, the addition of microorganisms to the soil had beneficial effect on the growth and physiological activity of the Virginia fanpetals, increasing, inter alia, the biomass yield [Piotrowski et al. 2016]. The correlations between the activity of soil enzymes and the content and uptake of macroelements demonstrated in the experiment confirm the importance of the intensity of removing nutrients from the soil environment [Pogrzeba et al. 2018; Wierzbowska et al. 2016].

\section{CONCLUSIONS}

1. The Virginia fanpetals had a higher yield potential in comparison with the multiflora rose. On the other hand, the multiflora rose responded to the application of sewage sludge with a higher yield increase compared to the Virginia fanpetals.

2 . The sewage sludge applied to the soil significantly increased the macroelement content in the tested plants. Higher content of $\mathrm{N}, \mathrm{Mg}, \mathrm{Ca}$, and $\mathrm{Na}$ was found in the Virginia fanpetals than in the multiflora rose. In turn, the multiflora rose was characterized with higher contents of $\mathrm{P}$ and $\mathrm{K}$ compared to the Virginia fanpetals.

3. The increasing doses of sewage sludge significantly raised the macroelement uptake by plants. The highest dose of sewage sludge reveled greater uptake of $\mathrm{N}$ and $\mathrm{Na}$ with the biomass yield by the Virginia fanpetals than by the multiflora rose. On the other hand, the multiflora rose took up more $\mathrm{P}, \mathrm{K}, \mathrm{Mg}$, and $\mathrm{Ca}$ than the Virginia fanpetals. 
4. The evaluation of the percentage phytoremediation revealed that the Virginia fanpetals used $\mathrm{N}, \mathrm{P}, \mathrm{K}, \mathrm{Na}$, and $\mathrm{Mg}$ to a greater extent than the multiflora rose. In contrast, the multiflora rose accumulated more Ca compared to the Virginia fanpetals.

5. On the basis of the yield, uptake, and phytoremediation, it can be concluded that the Virginia fanpetals is a plant with a great potential for the recycling of macroelements from the municipal sewage sludge.

\section{REFERENCES}

1. Abdul Khaliq, S.J., Al-Busaidi A., Ahmed M., AlWardy M., Agrama H., Choudri B.S. 2017. The effect of municipal sewage sludge on the quality of soil and crops. International Journal of Recycling of Organic Waste in Agriculture, 6, 4, 289-299. https://doi.org/10.1007/s40093-017-0176-4

2. Arduini I., Cardelli R., Pampana S. 2018. Biosolids affect the growth, nitrogen accumulationand nitrogen leaching of barley. Plant, Soil and Environment, 64, 3, 95-101. https://doi.org/10.17221/745/2017-PSE

3. Antonkiewicz J. 2010. Effect of sewage sludge and furnace waste on the content of selected elements in the sward of legume-grass mixture. Journal of Elementology, 15, 3, 435-443. DOI: 10.5601/ jelem.2010.15.3.435-443

4. Antonkiewicz J., Kołodziej B., Bielińska E. 2017. Phytoextraction of heavy metals from municipal sewage sludge by Rosa multiflora and Sida hermaphrodita. International Journal of Phytoremediation, 19, 4, 309-318. http://dx.doi.org/10.1080 /15226514.2016.1225283

5. Awasthi M.K., Wang M.J., Pandey A., Chen H.Y., Awasthi S.K., Wang Q., Ren X., Lahore A.H., Li D.S., Li R.H., Hang Z.Q. 2017. Heterogeneity of zeolite combined with biochar properties as a function of sewagesludge composting and production of nutrient-rich compost. Waste Management, 68, 760-773. https://doi.org/10.1016/j.wasman.2017.06.008

6. Bielińska E.J., Futa B., Baran S., Żukowska G., Olenderek H. 2015. Soils enzymes as bio-indicators of forest soils health and quality within the range of impact of Zaklady Azotowe 'Pulawy' SA. Sylwan, 159, 11, 921-930.

7. Borkowska H., Molas R. 2012. Two extremely different crops, Salix and Sida, as sources of renewable bioenergy. Biomass and Bioenergy, 36, 234-240. http://dx.doi.org/10.1016/j.biombioe.2011.10.025

8. Borkowska H., Molas R. 2013. Yield comparison of four lignocellulosic perennial energy crop species. Biomas and Bioenergy, 51, 145-153. http:// dx.doi.org/10.1016/j.biombioe.2013.01.017

9. Helios W., Kozak M., Malarz W., Kotecki A. 2014. Effect of sewage sludge application on the growth, yield and chemical composition of prairie cordgrass (Spartina pectinata Link.). Journal of Elementology, 19,4, 1021-1036, DOI: 10.5601/jelem.2014.19.3.725

10. Jones J.B., Case V.W. 1990. Soil testing and plant analysis. 3rd ed. Soil Science Society of America SSSA, Chapter 15.

11. Kacprzak M., Neczaj E., Fijałkowski K., Grobelak A., Grossem A., Worwag M., Rorat A., Brattebo H., Almås Å., Singh B.R. 2017. Sewage sludge disposal strategies for sustainable development. Environmental Research, 156, 39-46. DOI: https:// doi.org/10.1016/j.envres.2017.03.010

12. Kocon A, Jurga B. 2017. The evaluation of growth and phytoextraction potential of Miscanthus $\mathrm{x}$ giganteus and Sida hermaphrodita on soil contaminated simultaneously with $\mathrm{Cd}, \mathrm{Cu}, \mathrm{Ni}, \mathrm{Pb}$, and Zn. Environmental Science and Pollution Research, 24, 5, 4990-5000. https://doi.org/10.1007/ s11356-016-8241-5

13. Kołodziej B., Antonkiewicz J., Stachyra M., Bielińska E.J., Wiśniewski J., Luchowska K., Kwiatkowski C. 2015. Use of sewage sludge in bioenergy production - A case study on the effects on sorghum biomass production. European Journal of Agronomy, 69, 63-74. http://dx.doi.org/10.1016/j. eja.2015.06.004

14. Kołodziej B., Stachyra M., Antonkiewicz J., Bielińska E., Wiśniewski J. 2016. The effect of harvest frequency on yielding and quality of energy raw material of reed canary grass grown on municipal sewage sludge. Biomass and Bioenergy, 85, 363-370. http://dx.doi.org/10.1016/j.biombioe. 2015.12 .025

15. Korzeniowska J., Stanisławska-Glubiak E. 2015. Phytoremediation potential of Miscanthus $\mathrm{x}$ giganteus and Spartina pectinata in soil contaminated with heavy metals. Environmental Science and Pollution Research, 22, 15, 11648-11657. https:// doi.org/10.1007/s11356-015-4439-1

16. Kicińska A., Kosa-Burda B., Kozub P. 2018. Utilization of a sewage sludge for rehabilitating the soils degraded by the metallurgical industry and a possible environmental risk involved. Human and Ecological Risk Assessment. https://doi.org/10.10 80/10807039.2018.1435256

17. Krzywy-Gawrońska E. 2012. The effect of industrial wastes and municipal sewage sludge compost on the quality of Virginia fanpetals (Sida hermaphrodita Rusby) biomass Part 1. Macroelements content and their uptake dynamics. Polish Journal of Chemical Technology, 14, 2, 9-15. DOI: 10.2478/ v10026-012-0064-7

18. Ladd N., Butler J.H.A. 1972. Short-term assays of soil proteolytic enzyme activities using proteins 
and dipeptide derivatives as substrates. Soil Biol. Biochem., 4, 19-30.

19. Lee C.G., Alvarez P.J.J., Kim H.G., Jeong S., Lee S., Lee K.B., Lee S.H., Choi J.W. 2018. Phosphorous recovery fromsewagesludge using calcium silicate hydrates. Chemosphere, 193, 1087-1093. https:// doi.org/10.1016/j.chemosphere.2017.11.129

20. Nahm M., Morhart C. 2018. Virginia mallow (Sida hermaphrodita (L.) Rusby) as perennial multipurpose crop: biomass yields, energetic valorization, utilization potentials, and management perspectives. Global Change Biology Bioenergy, 10, 6, 393-404. DOI: https://doi.org/10.1111/gcbb.12501

21. Ostrowska A., Gawliński S., Szczubiałka Z. 1991. Methods of analysis and assessment of soil and plant properties. A Catalgoue. Publisher: Institute of Environmental Protection - National Research Institute, Warsaw, pp 334.

22. Piotrowski K., Romanowska-Duda Z., Grzesik M. 2016. Cyanobacteria, Asahi SL and Biojodis as stimulants improving growth and development of the Sidahermaphrodita L. Rusby plant under changing climate conditions. Przemysl Chemiczny, 95, 8, 1569-1573. DOI: 10.15199/62.2016.8.31.

23. Pogrzeba M., Rusinowski S., Krzyżak J. 2018. Macroelements and heavy metals content in energy crops cultivated on contaminated soil under different fertilization-case studies on autumn harvest. Environmental Science and Pollution Research, 25, 12, 1209612106. https://doi.org/10.1007/s11356-018-1490-8

24. Polish Soil Classification. 2011. Soil Science Annual, 62, 3, 1-193. http://www.ptg.sggw.pl

25. Regulation. 2015. Regulation of the Minister of the Natural Environment on municipal sewage sludge dated 6 February 2015. Journal of Laws of Poland, Item 257. http://isap.sejm.gov.pl/DetailsServlet?id =WDU20150000257

26. Regulation. 2016. Regulation of the Minister of the Natural Environment on how to conduct land surface pollution assessment dated 1 September 2016. Journal of Laws of Poland, Item 1395. http://isap. sejm.gov.pl/DetailsServlet?id=WDU20160001395

27. Sassenrath G.F., Schneider J.M., Gaj R., Grzebisz W., Halloran J.M. 2013. Nitrogen balance as an indicator of environmental impact: Toward sustainable agricultural production. Renewable Agriculture and Food Systems, 28, 3, 276-289. https://doi. org/10.1017/S1742170512000166

28. Schröder P., Beckers B., Daniels S., Gnädinger F., Maestri E., Marmiroli N., Mench M., Millan R., Obermeier M.M., Oustriere N., Persson T., Poschenrieder C., Rineau F., Rutkowska B., Schmid T., Szulc W., Witters N., Sæbø A. 2018. Intensify production, transform biomass to energy and novel goods and protect soils in Europe - A vision how to mobilize marginal lands. Science of The Total Environment, 616-617, 1101-1123. https://doi.org/10.1016/j.scitotenv.2017.10.209

29. Siekiewicz S., Wierzbowska J., Kovacik P., Krzebietke S., Zarczyński P. 2018. Digestate as a substitute of fertilizers in the cultivation of Virginia fanpetals. Fresenius Environmental Bulletin, 27, 6, 3970-3976.

30. Soil Survey Staff. 2014. Keys to Soil Taxonomy, 12th ed. USDA-Natural Resources Conservation Service, Washington, DC.

31. Symanowicz B., Kalembasa S., NiedbałaM., Toczko M., Skwarek K. 2018. Fertilisation of pea (Pisum sativumL.) with nitrogen and potassium and its effect on soil enzymatic activity. Journal of Elementology, 23, 1, 57-67. DOI. 10.5601/jelem.2017.22.1.1395

32. Tabatabai M.A., Bremner J.M. 1969. Use of p-nitrophenyl phosphate for assay of soil phosphatase activity. Soil Biol. Biochem. 1, 301-307.

33. Thalmann A. 1968. Zur methodik der bestimmung der Dehydrogenaseaktivit $\sim \mathrm{tt}$ im Boden mittels Triphenyltetrazoliumchlorid (TTC). Landwirtsch Forsch, 21, 249-258.

34. Tontti T., Poutiainen H., Heinonen-Tanski H. 2017. Efficiently treated sewagesludge supplemented with nitrogen and potassium is a good fertilizer for cereals. Land Degradation \& Development, 28, 2, 742-751. https://doi.org/10.1002/ldr.2528

35. Waste Catalogue. 2014. Regulation of the Minister of the Natural Environment on catalog of wastes dated 9 December 2014. Journal of Laws of Poland, Item 1923. http://isap.sejm.gov.pl/DetailsSer vlet?id=WDU20140001923

36. Wielgosz E. 1999. Aktywność mikrobiologiczna i enzymatyczna w glebie brunatnej pod uprawą ślazowca pensylwańskiego (Sida hermaphrodita Rusby) i topinambura (Helianthus tuberosus). Ann. UMCS., sect. E, 54, 21, 173-185.

37. Wierzbowska J., Sienkiewicz S., Krzebietke S., Sternik P. 2016. Sewage sludge as a source of nitrogen and phosphorus for Virginia fanpetals. Bulgarian Journal of Agricultural Science, 22, 5, 722-727.

38. Wolna-Maruwka A., Sulewska H., Niewiadomska A., Panasiewicz K., Borowiak K., Ratajczak K. 2018. The influenceof sewage sludge and a consortium of aerobic microorganisms added to the soil under a Willow plantation onthe biological indicators of transformation of organic nitrogen compounds. Polish Journal of Environmental Studies, 27, 1, 403-412. https://doi.org/10.15244/pjoes/74184

39. Zantua M.I., Bremner J.M. 1975. Comparison of methods of assaying urease activity in soils. Soil Biol. Biochem. 7, 291-295.

40. Zapałowska A., Puchalski C., Hury G., Makarewicz A. 2017. Influence of fertilization with the use of biomass ash and sewage sludge on the chemical composition of Jerusalem artichoke used for energy-related purposes. Journal of Ecological Engineering, 18, 5, 235-245. https://doi. org/10.12911/22998993/76214 